\title{
THE GRAY JAY IN SASKATCHEWAN
}

by Joyce L. Smith, Regina

Just before noon on Thanksgiving Monday, October 11, 1965, we were driving along the lake in front of the Legislative Buildings in Regina. My husband drew my attention to a large gray bird flitting along in the trees which were almost bare of leaves. Being larger than a robin, the bird at first sight appeared to be a jay. Although we had never seen one before, it was obvious from Peterson's $A$ Field Guide To Western Birds that this was a Gray Jay (Perisoreus canadensis), formerly known as the Canada Jay. Upon returning home we checked the status of this bird in Belcher's Birds of Regina, and found it listed as rare for the Regina area.

A further study of Peterson's Guide showed that the Gray Jay is commonly found in the "boreal forests of N. America." Within its western range this species is "resident from the tree limit in Alaska, N. Canada south through boreal forests of W. Canada; through Pacific states to N. California (not Sierra) ; in Rocky Mt. region to Arizona, N. New Mexico; also Black Hills."

Seeing the bird in Regina outside its normal range prompted me to investigate the range and status of the Gray Jay in Saskatchewan. By writing many letters of inquiry and perusing available literature, I was able to gain a better understanding of its appearance in Saskatchewan.

Basically, Saskatchewan falls within two of the five major vegetational regions of North America (tundra, coniferous forest, deciduous forest, grassland, desert) as shown by Wallace (1963). Northern Saskatchewan is a vast expanse of coniferous or boreal forest which in the extreme northeast corner gives way to a transitional thinning of the vegetation toward the treeless tundra further north. Approximately the southern one-third of the province lies in the prairie region of the Great Plains. Forming an area of transition between the heavy coniferous forest (chiefly spruce) of the north, and the wideopen grassland of the south is a belt of aspen grove often referred to as "parkland."

As one would expect, the Gray Jay is known to be a common permanent resident in the boreal forest of northern Saskatchewan. Nero (1963:104105) reports numerous and varied records from such northerly places as Black Lake, Cree River, and Fond du Lac (all east and southeast of Lake Athabasca), and Lake Athabasca. In Prince Albert National Park (Soper, $1952: 1-8,54)$ the Gray Jay may be seen all over the Park at any time of year, though it is more commonly found in the northern coniferous parts, where white spruce predominates, than in the southern edge with its woods of poplar and birch.

The Gray Jay occurs commonly in Saskatchewan's boreal forest right to its southern boundaries. In the Flotten Lake area, located in the northeast corner of Meadow Lake Provincial Park in western Saskatchewan, and described by Godfrey (1950:1-11, 54) as a "forest of transition from aspen grove to coniferous forest," the Gray Jay is also a common permanent resident. Nesting records for this species are reported for both the Prince Albert and Nipawin areas (Houston and Street, 1959:124-131). At Somme, southeast of Tisdale, the Gray Jay is also commonly seen in this predominantly heavy forest area (Hooper and Hooper, 1954:1,9).

Moving south into the parkland region there is a transitional thinning of the vegetation accompanied by a distinct drop-off of the occurrence of the Gray Jay. Within its normal range in the boreal forest of northern Saskatchewan, this species may be seen at any time of year, and in numbers from two at a time to as many as a dozen or more birds in any one area. In the parkland, reports usually show one or two birds seen only dur- 
ing the winter months, every two, three or even four years.

The area chosen by Houston (1949: 215,233 ) for his study of the birds of the Yorkton district, was within a 40 mile radius of Yorkton, the boundaries slightly altered to keep the study area within the parkland belt. In the Yorkton area, the Gray Jay was "noted some winters, as a wanderer from its breeding grounds just north of this district. J. Gunn reports that this species was so common in the fall and winter before the turn of the century that it was a nuisance to the trappers at Good Spirit Lake." William Anaka (pers. corres., 1965) has been keeping records at Spirit Lake since 1950 . He states that "despite our proximity to the coniferous area this species may be considered as uncommon and irregular. It has been present during all or part of the winter season for only five of the last 15 years."

At Saskatoon, J. B. Gollop of the Canadian Wildlife Service (pers. corres., 1965) reports the Gray Jay as "an irregular winter visitant. Four birds were seen on the Christmas count in December 1955, and single birds were seen on March 1, 1959, October 8, 1960, and April 1, 1961.

Spencer Sealy (pers. corres., 1965) describes the Gray Jay as a "sporadic winter visitor in the Battleford area." His personal records show this species only once in eight years, that being the winter of 1958-59 when one or two birds were seen on six different occasions. The only other record for this area is of one bird seen by Harold Fisher southeast of Battleford on November 13, 1965.

Manley Callin at Fort San reported by phone that he has seen only one Gray Jay in his 22 years in that area. Fort San is in the Qu'Appelle Valley, within the aspen grove belt as it swings into southeastern Saskatchewan.

Outside the parkland on the Saskatchewan prairies the status of the Gray Jay can be summed up in one word, rare. Following no apparent pattern of regularity and for no obvious reason, the Gray Jay makes its appearance on the prairies almost entirely during the winter months.

Belcher's records $(1961: 50,54,55)$ show that this jay has been recorded irregularly in the Regina area in the winter. Sometimes the bird or birds spent some weeks in the area. The Saskatchewan Museum of Natural History file shows that one or two of these birds were seen several times from September 27, 1919 to January 10, 1920. Doug Gilroy had a lone bird at his farm home on Boggy Creek from November 17, 1952 to January 17,1953 ; and one was seen on October 23, 1958 (by F. McKay) and through the winter to March 9, 1959. Other sightings of this species at Regina were almost always records of a single bird seen on a single occasion, with the exception of two seen at the Legislative Grounds on December 7, 1946, and three in late fall 1955 in the Wascana district (Regina west).

Also in southeastern Saskatchewan there is a record of one Gray Jay seen at Lumsden on December 25, 1964 by A. Binnie, and a single record for Moose Jaw of one bird on December 20, 1964 by Mrs. F. B. Taylor (Lister, 1965).

Glen Fox (pers. corres., 1965) has records of individual birds of this species spending the winter in and around Kindersley in west-central Saskatchewan in 1956-57, 1961-62, and 1964-65.

Finally, in reviewing the occurrences of the Gray Jay on the Saskatchewan prairies, there is a record contributed by Steve Mann (pers. corres., 1965) from Skull Creek in southwestern Saskatchewan. He writes that in November and December 1961 there "was a lone bird seen around our ranch house... where there is quite a bit of bush, willow, aspen ... also a few evergreens in a shelter belt." He also recalls lone members of this species seen in this area in the spring of 1963 and during the winter of 1964 .

Thus, in summary, it can be said that the Gray Jay is a common permanent resident in the heavy coniferous forest of northern Saskatche- 


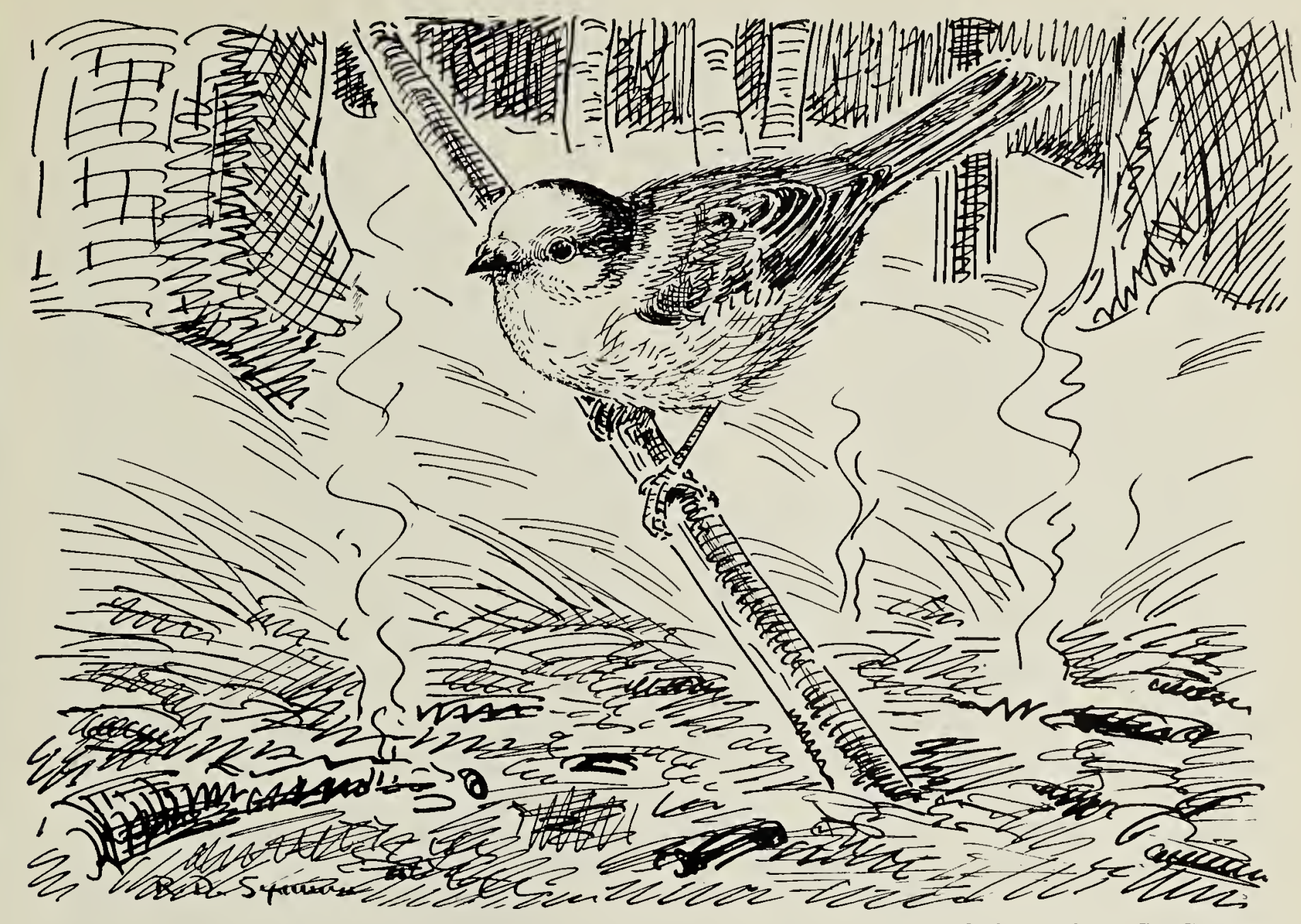

Sketch by Robert D. Symons

GRAY JAY: "When the woodsman leaves his camp fire he puts his tea-pail stick upright in the middle. Then the Whiskey-jacks make a final inspection!"

wan, much less common and seen irregularly during the winter months in the parkland belt, and rare on the prairies.

A similar distribution appears to hold true for each of the other two prairie provinces, Alberta and Manitoba. Dr. Robert Lister (pers. corres., 1965) at the University of Alberta in Edmonton presented a concise account of this species in that province: "of course common throughout the coniferous forests to the north and west of us. They occur all the way down the mountains. We occasionally have movements of these jays into other areas of the parkland in fall but these are most irregular and occur without any obvious reason. As far as I know there are no records of the Gray Jays from the Alberta prairies." The prairie region in Alberta occupies the southeast corner of the province from the foothills east into Saskatchewan. The Alberta park- land belt extends from just north of Calgary to just north of Edmonton, again from the foothills east into Saskatchewan.

In Manitoba, the prairie region proper is restricted to the extreme southwest corner of the province. At Oak Lake, west of Brandon, David Hatch (pers. corres., 1965) concludes "that the Gray Jay is an irregular visitor to Oak Lake. All observations show it is present only in the late fall and winter." Although prior to and including 1954 this species was quite commonly seen in the Assiniboine River Valley near Oak Lake, only scattered reports are available from 1954 up to 1960 and "since 1960 a Gray Jay has not been seen in the Oak Lake area."

Harold Mossop of Winnipeg reported to Hatch that he had not seen any birds of this species in the Turtle Mountains during his "annual deer hunting" between 1962 and 1965 . 
This species is known to breed in the boreal forest sections within the parkland of south-southeastern Manitoba-Spruce Woods, Agassiz, Sandilands, Whiteshell, and Northwest Angle Forest Reserves. Still in the parkland belt, but in a boreal forest habitat at Riding Mountain National Park in western Manitoba, "it is a regular breeding bird and is seen in very small to good numbers every fall and winter at Birtle" (Hatch).

$A$ review of the Newsletters put out by the Natural History Society oI Manitoba since 1962 presents a good picture of the Gray Jay in that province. Herb Copland reported that "a single bird of this species observed just south of Selkirk, on May 3 [1962], was well outside its normal range for this date." Presumably again the Gray Jay is known in this parkland area only as a winter visitor. Other scattered sightings available for the southeastern area of Manitoba occurred in December and January and in very small numbers at Winnipeg, Marchand, Great Falls, Seven Sisters Falls (Newsletters), and at Pinawa (Stewart, 1965:97).

In the more northern coniferous regions of Manitoba the Gray Jay is known to be a year-round resident. A study of The birds of the Pikwitonei Area of Manitoba appeared in the Natural History Society of Manitoba Newsletter in 1963. Herb Copland and Gordon Smith reported the Gray Jay in July 1949 and June 1950 in this settlement in north-central Manitoba on the Hudson Bay Railroad, as "noted regularly," with immatures "seen on several occasions."

In the three prairie provinces, as we have seen, the Gray Jay is known to be almost exclusively a bird of the coniferous forest, where it is a permanent (year-round) resident. To a small degree this species has been known to breed in willow, muskeg, or aspen; but even then it remains in close proximity to the coniferous forest. Lister (1965) reports that "the birds breed in the muskeg about six miles west of the city of Edmonton." Bent (1946) also states that "in the more northern portions of its range it is often found in opener upland forests, nesting sometimes in solitary trees or clumps of willows."

Why then do we on rare occasions see one of these birds on the prairies? Focd shortages in the boreal forest in winter may provide part of the explanation. I personally consider our sighting in Regina in October 1965, as well as other records on the prairies, as only individual wanderers. Another important question is: Where are these birds coming from? Birds seen on the prairies, and thus well outside their normal range, we think of having "come down from the north." Although in the majority of cases this may be true, it must not be forgotten that they could be coming in from the mountains to the west or even from the southwest and south (see map). Southeastern British Columbia, northern Idaho, western Montana, and southwestern Alberta are all common breeding places for this species (Bent, 1946). What about the Black Hills in South Dakota? In this "outlying range of the Rocky Mountains" the "most conspicuous and extensive formation" is the coniferous forest "dominated by Ponderosa Pine" (Pettingill and Whitney, 1965). The Gray Jay is a "fairly common" breeding species in the denser stands of pine forest in the Black Hills (at elevations above 4000 feet). Interestingly enough, buttes with coniferous cover extend from the Black Hills practically to the border of Saskatchewan, but their bird life has not been extensively studied. Considering the continuity of this coniferous vegetation through an area generally regarded as prairie, and the possible build-up of population in the rather restricted locality of the Black Hills, it is tempting to speculate that our Gray Jays could have moved up from the south. This possibility, however, appears remote, and it is usual to ask whether the jays we see on the prairies in winter are from the north or the west, since the Alberta-Saskatchewan prairies are almost equally distant from the coniferous areas of the north and the mountainous regions of the west. 


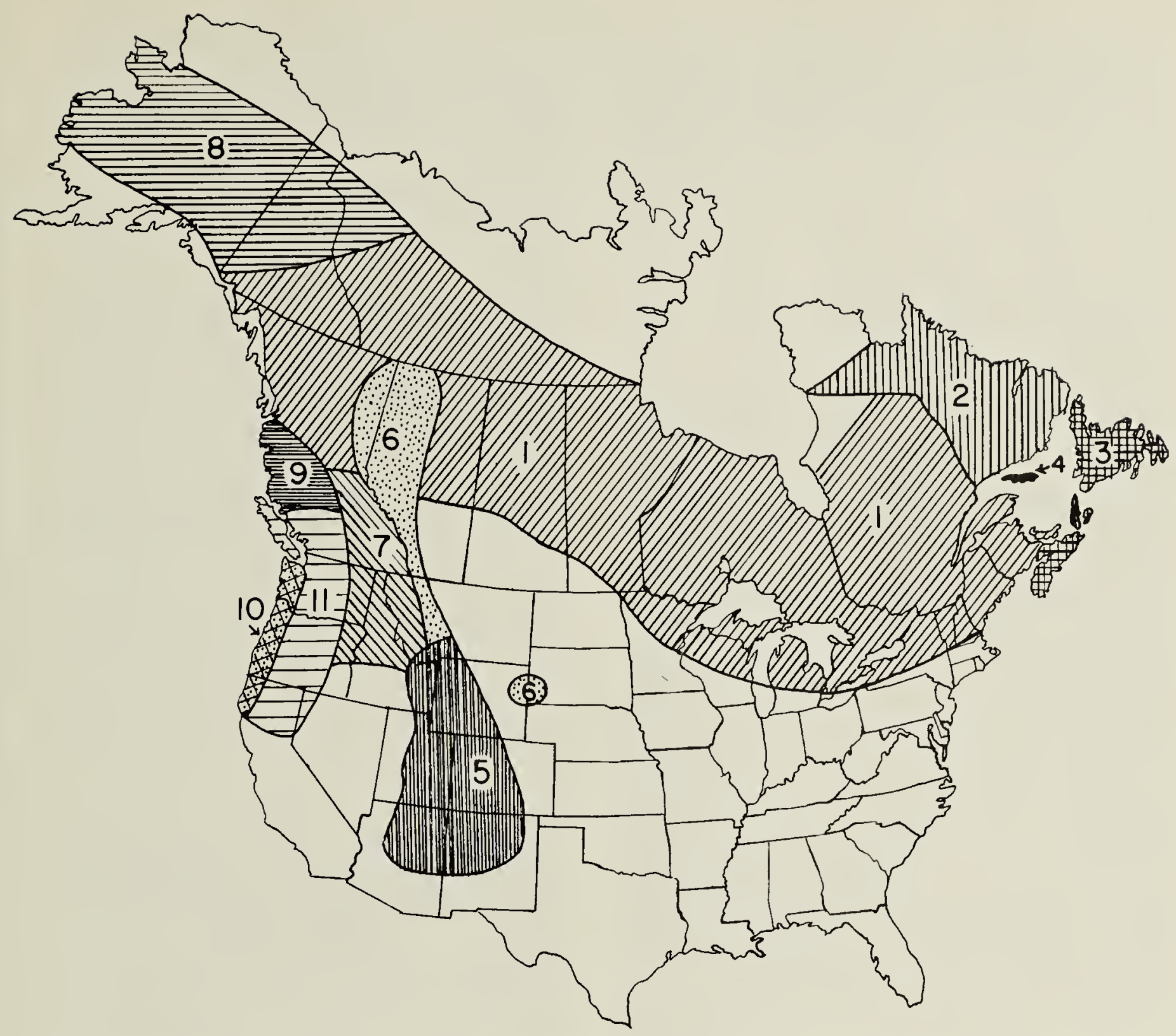

Approximate ranges of the 11 subspecies of the Gray Jay (drawn from reference to: A.O.U., 1957) : 1. Perisoreus canadensis canadensis (Linnaeus); 2. P. c. nigricapillus Ridgway; 3. P. c. sanfordi Oberholser; 4, P. c. barbouri Brooks; 5. P. c. capitalis Ridgway; 6. P. c. albescens Peters; 7. P. c. bicolor Miller; 8. P. c. pacificus (Gmelin); 9. P. c. arcus Miller; 10. P. c. obscurus Ridgway; 11. P. c. griseus Ridgway.

Dr. M. T. Myres (pers. corres., 1965) of the University of Alberta at Calgary states that the Gray Jay seen at Regina "probably came from the north rather than the west." It is his feeling that if jays had been coming from the western mountain range to the prairies "some might have been reported at Calgary. In fact there is no evidence of this at all." Similarly Lister suggests: "it seems to me that if there have been more or less regular movements of Gray Jay from the mountains across the southern Canadian prairies, the birds over the years might have populated the Cypress Hills. As far as I know again, there are no records from this predomin- antly coniferous area." In fact, Godfrey's study of the Cypress Hills revealed that the Gray Jay is not known to occur in the Hills in southwestern Saskatchewan. Mrs. Bower Good (pers. corres., 1965) of Maple Creek who spends her summers at Cypress Park, reports that, "I have never seen one there, nor has one of the Park managers whom I contacted."

Although these opinions support the idea that Gray Jays probably move into the plains of southein Saskatchewan from the north, we know that some unusual birds known in the mountains to the west have occasionally appeared in Regina during migra- 
tion-for example, the Varied Thrush and Townsend's Solitaire (Belcher, 1961). The day after we had seen the Gray Jay last October, Frank Brazier sighted a lone Varied Thrush, also in the Legislative Grounds (Brazier, 1965), and we considered it to be quite likely that both birds had arrived in a general movement from the west.

We might have the answer to this question if we were able to determine the race or subspecies of the Gray Jay that visits the prairies in winter. The A.O.U. in its 1957 checklist outlines the ranges for 11 subspecies of Perisoreus canadensis. The combined ranges of these individual subspecies as shown on the accompanying map represent the known range of the Gray Jay in North America. Only through extensive banding programs or taxonomic studies of specimens would it be possible to determine which form or forms of the Gray Jay are being seen in southern Saskatchewan and thus to conclude whether they are coming from northern Saskatchewan or from the west.

\section{ACKNOWLEDGEMENTS}

My sincere appreciation is extended to all those who took the time and effort to answer my requests for information on the Gray Jay.

A special thank you to Margaret Belcher for the use of her records and for her editorial assistance; to Dr. R. W. Nero for his guidance and the use of his library; and to my husband for his patience and encouragement.

\section{LITERATURE CITED}

American Ornithologists' Union. 1957. Checklist of North American birds. Fifth ed. Baltimore.

Belcher, Margaret. 1961. Birds of Regina. Spec. Pub. No. 3. S.N.H.S., Regina.

Bent, A. C. 1946. Life histories of North American jays, crows, and titmice. U.S. Nat. Mus. Bull. 191.

Brazier, F. H. 1965. Varied Thrush continues to visit Regina. Blue Jay, $23(4): 160$.

Godfrey, W. E. 1950. Birds of the Cypress Hills and Flotten Lake Regions, Saskatchewan. Nat. Mus. of Can., Bull. 120.

Hooper, D., and R. Hooper. 1954. A preliminary list of the birds of the Somme District,
Sask. Contribution No. 3. Yorkton Natural History Society. Mimeo.

Houston, C. S. 1949. The Birds of the Yorkton District, Saskatchewan. Can. Field - Nat., $63(6): 215-241$.

Houston, C. S., and M. G. Street. 1959. The birds of the Saskatchewan River, Carlton to Cumberland. Spec. Pub. No. 2. S.N.H.S., Regina.

Lister, R. 1965. Ed. Northern Great Plains section. Audubon Field Notes 19(3):393.

Nero, R. W. 1963. Birds of the Lake Athabasca region, Saskatchewan. Spec. Pub. No. 5. S.N.H.S., Regina.

Peterson, R. T. 1961. A field guide to western birds. 2nd edition. Houghton Mifflin, Boston.

Pettingill, Jr., O. S., and N. R. Whitney, Jr. 1965. Birds of the Black Hills. Spec. Pub. No. 1. Cornell Laboratory of Ornithology. Ithaca, New York.

Soper, J. D. 1952. The birds of Prince Albert National Park, Saskatchewan. Wildlife Mgt. Bull., Series 2, No. 4, Can. Wildlife Service, Ottawa.

Stewart, R. B. 1965. Compiler. Christmas bird count (1964). Pinawa, Manitoba. Audubon Field Notes, 19(2).

\section{FURTHER NOTE ON THE BLACK-HEADED GROSBEAK IN MANITOBA}

\section{by Martin McNicholl, Winnipeg}

In a recent Blue Jay (23:77-78, June, 1965), I summarized the Manitoba and Saskatchewan records of the Black-headed Grosbeak. However, since writing that note, I have found in the late A. G. Lawrence's Chickadee Notes - (Winnipeg Free Press, May 31, 1947) the following migration note: "Black-headed Grosbeak, male, May 21. Mrs. L. K. Sowls, Delta, Man."

Mr. Lawrence gave further details in "Chickadee Notes" No. 1359 (June 7, 1947), as follows: "Westerner Visits Delta, Man. Mrs. L. K. Sowls, Delta, Man., found a single male Black-headed Grosbeak on May 21. It was also seen by Mr. Sowls and Harry G. Anderson of the U.S. Fish and Wildlife Service. Both Mrs. Sowls and Mr. Anderson were familiar with this western species in California ..."

If any Blue Jay reader knows of any other Manitoba or Saskatchewan records, I would be very interested to hear about them. 